\title{
THE INFLUENCE OF VASOPRESSIN ON THE PERMEABILITY OF THE MAMMALIAN COLLECTING DUCT TO UREA*
}

\author{
By JOHN R. JAENIKE $\dagger$ \\ (From the Laboratory of Kidncy and Electrolyte Metabolism, National Heart Institute, \\ Bethesda, Md.)
}

(Submitted for publication June 9, 1960; accepted August 11, 1960)

The efficient operation of the renal concentrating mechanism is dependent upon the action of vasopressin on the permeability of the distal convoluted tubule to water (1). In the presence of this hormone, hypotonic fluid entering the distal convolution equilibrates osmotically with fluid in the surrounding renal cortical tissue, and isotonicity of the fluid delivered to the collecting ducts is achieved $(1,2)$. The collecting ducts are surrounded by a medullary interstitium which is variably hyperosmolal to plasma (3-5). The osmotic movement of water from collecting duct lumen to medullary interstitium results in the excretion of a hypertonic urine. Despite evidence that movement of water across the collecting duct epithelium may occur in the apparent absence of vasopressin $(6,7)$, most schemes of the urinary concentrating process inclucle the hypothesis that water permeability in this segment of the nephron is enhanced by this hormone. The present study was designed to test that hypothesis.

Kinetic analysis of the action of vasopressin on the movement of water and solute across the toad skin indicates that the hormone acts to increase the pore size in this epithelial membrane $(8,9)$. If vasopressin exerts a similar action on the collecting duct epithelium, the permeability of the membrane to various partially permeant solutes should be affected by this agent. Since the urea concentration within the collecting duct fluid rises as water is abstracted from the lumen (10), it may be concluded that this membrane offers a barrier to the free diffusion of this molecule. It was therefore anticipated that an effect of vasopressin on the permeability of the collecting duct epithelial

\footnotetext{
*Presented before the joint meeting of the American Federation for Clinical Research and the American Society for Clinical Investigation, Atlantic City, N. J., May 1, 1960.

† Present address: Department of Medicine, University of Rochester School of Medicine and Dentistry, Rochester, N. Y.
}

membrane would be manifested by an increased rate of movement of urea across this membrane. The experiments to be described indicate that vasopressin does augment the movement of urea from the collecting duct lumen to the medullary interstitial fluid. The present results are in accord with the recent report of Maffly, Hays, Lamdin and Leaf (11) which demonstrates that vasopressin markedly increases the permeability of the isolated toad bladder to urea.

The studies of Schmidt-Nielsen and O'Dell have suggested the presence of a specific transport mechanism for urea within the distal tubular system of the sheep (12). As discussed by Levinsky and Berliner (13), however, the present experimental evidence in the dog is entirely compatible with the hypothesis that urea enters the medullary tissue space of this species by passive diffusion along a concentration gradient. Whereas the data to be presented in no way refute the possibility of active transport of urea in the dog nephron (or an effect of vasopressin on this hypothetical transport system), they are fully compatible with the concept of solely passive movement of urea.

\section{METHODS AND PROCEDURES}

All studies were performed in anesthetized mongrel dogs, in two distinct groups of experiments.

I. The relative concentrations of urea in the urine and in the medullary tissue were determined during the steady state. Studies were done at high urine flow rates, and at relatively low urine to plasma urea concentration ratios, so that the urea concentration in the urine would closely approximate that in the terminal portion of the collecting duct system.

The protocol of a representative experiment is outlined in Table I. Anesthesia was induced and maintained with thiopental sodium. Both ureters were catheterized through flank incisions, and urine was collected separately from each kidney. Following induction of anesthesia, an intravenous water load consisting of 2.5 per cent glucose in water, equivalent to 4 to 5 per 
TABLE I

Comparison of medullary and urinary urea concentrations during water diuresis and during the administration of vasopressin and mannitol; protocol of a single experiment *

\begin{tabular}{|c|c|c|c|c|c|c|c|c|}
\hline & \multicolumn{4}{|c|}{ Right kidney } & \multicolumn{4}{|c|}{ Left kidney } \\
\hline & $\mathrm{V}$ & $\mathrm{U}_{\text {urea }}$ & $\mathrm{U}_{\text {osm }}$ & $C_{\text {in }}$ & $\mathrm{V}$ & Uurea & $\mathrm{U}_{\text {osm }}$ & $\mathrm{C}_{\text {in }}$ \\
\hline $\min$ & $\mathrm{ml} / \mathrm{min}$ & minoles/L & $m O s m / k g$ & $\mathrm{ml} / \mathrm{min}$ & $\mathrm{ml} / \mathrm{min}$ & mmoles/L & $\mathrm{mOsm} / \mathrm{kg}$ & $\mathrm{ml} / \mathrm{min}$ \\
\hline 0 & \multicolumn{8}{|c|}{ Anesthetized with $2.5 \%$ thiopental sodium } \\
\hline $5-30$ & \multicolumn{8}{|c|}{ Operation, both ureters catheterized } \\
\hline $10-55$ & \multicolumn{8}{|c|}{ IV ater load, $560 \mathrm{ml} 2.5 \%$ glucose in water i.v. } \\
\hline 35 & \multicolumn{8}{|c|}{ Infusion, inulin, $40 \mathrm{mg} / \mathrm{ml}$ at $0.25 \mathrm{ml} / \mathrm{min}$} \\
\hline 50 & \multicolumn{8}{|c|}{ Infusion, $140 \mathrm{mmoles} / \mathrm{L}$ urea in $2.5 \%$ glucose in water at $9.0 \mathrm{ml} / \mathrm{min}$} \\
\hline $133-148$ & 4.65 & 60.0 & 74 & 33.5 & 5.13 & 56.6 & 79 & 39.8 \\
\hline $148-163$ & 4.73 & 64.1 & 83 & 39.8 & 5.20 & 60.5 & 80 & 37.8 \\
\hline $163-178$ & 4.52 & 72.0 & 90 & 43.0 & 4.93 & 66.5 & 90 & 37.8 \\
\hline 179 & \multirow{3}{*}{\multicolumn{8}{|c|}{$\begin{array}{l}\text { Left kidney removed } \\
\text { Infusions changed to: } 5 \% \text { mannitol }+180 \mathrm{mmoles} / \mathrm{L} \text { urea at } 3.2 \mathrm{ml} / \mathrm{min} \text {; } \\
\quad 40 \mathrm{mg} / \mathrm{ml} \text { inulin at } 0.115 \mathrm{ml} / \mathrm{min} \\
\text { Pitressin, } 400 \mathrm{mU} \text { i.v. immediately, and } 50 \mathrm{mU} / \mathrm{kg} / \mathrm{hr}\end{array}$}} \\
\hline \multirow[t]{2}{*}{185} & & & & & & & & \\
\hline & & & & & & & & \\
\hline $315-330$ & 6.77 & 49.1 & 227 & 37.4 & & & & \\
\hline $330-345$ & 6.88 & 58.5 & 230 & 41.9 & & & & \\
\hline $345-360$ & 6.46 & 60.5 & 238 & 45.0 & & & & \\
\hline 361 & \multicolumn{8}{|c|}{ Right kidney removed } \\
\hline
\end{tabular}

* Dog Ka; weight, $14.1 \mathrm{~kg}$.

cent of body weight, was given. Thereafter urea was infused in order to achieve relatively high urine and tissue concentrations, and to permit accurate determinations of urea in small tissue slices. When a water diuresis had been achieved, and the urine flow rate was essentially stable, three 15 -minute clearance periods were collected from each kidney. Immediately after the termination of the third clearance period, the left renal pedicle was clamped and the kidney removed. Vasopressin (aqueous Pitressin; Parke, Davis) was then given, 300 to $400 \mathrm{mU}$ intravenously immediately, and a sustaining infusion of $50 \mathrm{mU}$ per $\mathrm{kg}$ per hour. Mannitol was infused in order to maintain a high urine flow rate from the remaining right kidney. Urea infusion was continued. At the time a relatively stable urine flow was achieved, 3 clearance periods were collected, at the termination of which the right kidney was removed. Inulin was given throughout the procedure by means of a constant infusion pump. In three experiments, as shown in Table III, the above procedure was reversed. Mannitol and vasopressin were given at the outset of the experiment, and after removal of one kidney, these were withdrawn, the animal was given a water load, and the second kidney was removed when a water diuresis was attained.

Immediately following removal, sections were taken from each kidney for analysis. Serial adjacent slices were cut from the papilla and inner medulla by methods previously described (4). These were homogenized in water and urea analyses were performed on the homogenates. Aliquots from each area were dried in an oven for the determination of the tissue water content. The urea concentration per unit of tissue water could then be calculated. Urea was determined in tissue homogenates and urine specimens by the Conway micro-diffusion method (14). Inulin was determined in urine and plasma by reaction with diphenylamine, following alkali digestion (15). The osmolality of urine and plasma was determined by the method of Bowman, Trantham and Caulfield (16). Statistical analysis of the data in Table III was performed by methods described by Snedecor (17).

II. In order to determine the effect of vasopressin on the flux rate of urea into the renal medulla, a second set of experiments has been performed. Paired studies were done during water diuresis and during the infusion of vasopressin and mannitol. As in the previous set of experiments, urea was added to each infusion and 2 to 3 clearance periods were collected when a stable urine flow was attained. Five minutes before the removal of each kidney, an intravenous infusion of $\mathrm{C}^{14}$ labeled urea was started. Five urinary collection periods, each of 30 seconds' duration, preceded the removal of each kidney. The kidney was sectioned as described, except that in addition to sections from the papilla and inner medulla a slice of cortical tissue was also removed for analysis. Analyses for urea and water concentrations in the tissues were performed. In addition, an aliquot of each homogenate was counted in a liquid scintillation counter (Tri-Carb) for $\mathrm{C}^{14}$ activity. Urine specimens were similarly analyzed for urea and counted for $\mathrm{C}^{\mathbf{1 4}}$. Specific activities were calculated for tissue and urine specimens. All specimens from the second (vasopressin plus mannitol) part of the experiment were corrected for residual radioactivity by subtracting the specific activity of a urine collected immediately prior to the second infusion of isotope. This correction was minimized 
by administering approximately twice as much isotope in the second infusion. Correction for quenching was achieved by the internal standard method. Following initial counting of urine and tissue specimens, a uniform amount of $\mathrm{C}^{14}$-urea standard was added to each specimen, the counting procedure repeated, and the counts recorded compared with those from the same amount of standard added to an identical volume of water in the liquid phosphor system. Quenching was minimal (less than 5 per cent) in urine, medullary and papillary specimens, and appreciable only in cortical homogenates.

\section{RESULTS}

I. The effect of vasopressin on the relative urea concentrations in the urine and in the renal medulla. The ratio of the urea concentration in the inner medulla and papilla to that in the urine has been compared during water diuresis, and during the infusion of vasopressin and mannitol in 12 paired experiments. The protocol of a single representative experiment is shown in Table $\mathrm{I}$, and the tissue analyses from this experiment are detailed in Table II. The highest tissue urea concentration (expressed as micromoles per gram of water) was always present in either the papillary slice or that from the immediately adjacent inner medullary zone (designated as "Inner medulla, 1" in Table II). By relating the highest tissue urea concentration to the urinary urea concentration in the clearance period immediately preceding nephrectomy, a tissue to urine concentration ratio for urea has been computed. In the experiment tabulated, this ratio was higher during the administration of vasopressin than during water diuresis. This has been a consistent finding in each of 12 consecutive paired experiments, as shown in

TABLE II

Relationship of tissue to urinary urea concentrations in Dog Ka

\begin{tabular}{|c|c|c|c|}
\hline & $\begin{array}{l}\text { Tissue } \\
\text { urea }\end{array}$ & $\begin{array}{l}\text { Urine } \\
\text { urea }\end{array}$ & $\begin{array}{c}\text { Tissue/ } \\
\text { urine } \\
\text { conc. } \\
\text { ratio }\end{array}$ \\
\hline & 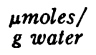 & $\underset{m l}{\mu m o l e s /}$ & \\
\hline \multicolumn{4}{|l|}{ I. Water diuresis } \\
\hline $\begin{array}{l}\text { Papilla } \\
\text { Inner medulla, } 1 \\
\text { Inner medulla, } 2\end{array}$ & $\begin{array}{l}48.0 \\
48.3 \\
41.5\end{array}$ & 66.5 & 0.726 \\
\hline \multicolumn{4}{|c|}{ II. Vasopressin and mannitol } \\
\hline $\begin{array}{l}\text { Papilla } \\
\text { Inner medulla, } 1 \\
\text { Inner medulla, } 2\end{array}$ & $\begin{array}{l}56.3 \\
54.7 \\
42.5\end{array}$ & 60.5 & 0.931 \\
\hline
\end{tabular}

TABLE III

Tissue to urine urea concentration ratios in 12 paired experiments

\begin{tabular}{lcc}
\hline \hline Dog & $\begin{array}{c}\text { Water } \\
\text { diuresis } \\
\text { Tissue/urine } \\
\text { concentration }\end{array}$ & $\begin{array}{c}\text { Vasopressin } \\
\text { urannitol }\end{array}$ \\
\hline $\mathrm{G}$ & 0.78 & 0.92 \\
$\mathrm{H}$ & 0.48 & 0.62 \\
$\mathrm{Ka}$ & 0.73 & 0.93 \\
$\mathrm{Q}^{*}$ & 0.62 & 0.91 \\
$\mathrm{~T}$ & 0.57 & 0.92 \\
$\mathrm{~V}$ & 0.62 & 0.71 \\
$\mathrm{C}$ & 0.61 & 0.70 \\
$\mathrm{~B}$ & 0.68 & 0.95 \\
$\mathrm{E}$ & 0.50 & 0.74 \\
$\mathrm{~K}^{*}$ & 0.86 & 0.92 \\
$\mathrm{~N}^{*}$ & 0.74 & 0.84 \\
Mean & 0.77 & 0.88 \\
SE of the mean difference & 0.027 \\
& 0.603 & \\
\hline
\end{tabular}

* Experiments in which the usual order of procedure was reversed. Vasopressin and mannitol were given initially; the second kidney was removed during water diuresis.

Table III. The difference in the means of the urea concentration ratios during water diuresis and vasopressin infusion is highly significant statistically. As indicated in Table III, in three dogs in which the order of the experiment was reversed, the differences in the urea concentration ratios were comparable with the remainder of the group.

As measured by the clearance of inulin, unilateral nephrectomy did not appear to produce significant hemodynamic changes in the remaining kidney. As in the experiment detailed in Table I, slight changes in inulin clearance were observed during the course of single experiments. These were not consistent in magnitude or direction, however, and the mean of all inulin clearances performed during water diuresis was identical with those measured during the administration of mannitol and vasopressin.

The relatively high tissue to urine urea concentration ratios observed during the administration of vasopressin and mannitol can not be attributed solely to the presence of a mannitol diuresis. In three paired experiments, during which vasopressin was infused throughout, the effect of sodium chloride diuresis was compared with that of mannitol infusion at comparable rates of solute excretion. Kidneys removed during sodium chloride infusion showed a tissue to urine urea concentra- 
tion ratio which was not different from the ratios observed during mannitol diuresis in the same animals.

These data indicate that vasopressin reduces the concentration gradient of urea between the collecting duct lumen and the medullary interstitium. Since present evidence indicates that in the dog, urea enters the medullary interstitial space (and presumably the cells of this area) by passive diffusion along a concentration gradient (13), these results suggest that vasopressin increases the permeability of the collecting duct epithelium to urea. However, an alternative explanation for these data has been considered, namely that the rate of removal of urea from the medullary interstitium is more rapid in water diuresis than during vasopressin and mannitol administration. Since a high concentration of urea within the medulla is maintained by the countercurrent exchanger effect provided by the medullary circulation, the efficiency with which urea is trapped within the medulla will vary inversely with the rate of blood flow through the capillary loops. If, during vasopressin action, either the rate of flow entering the capillary loops or the rate at which water abstracted from the collecting ducts is added to the medullary circulation is less than during water diuresis, the rate of washout of urea from the medulla would be correspondingly reduced. If either of these conditions exists, vasopressin might increase the tissue to urine concentration ratio for urea without affecting tubular permeability. It was therefore decided to determine the effect of vasopressin on the rate at which infused isotopic urea entered the medullary tissue during the steady state with respect to the urinary, and presumably medullary, urea concentration. This would serve as a measure of the turnover rate of urea in the medulla, which should be reduced if the vasopressin effect elicited in the above set of experiments were due solely to a reduction in the rate at which urea was washed out of the medullary interstitium. In addition, the effect of vasopressin on the rate of equilibration of isotopic urea between urine and renal medulla has been evaluated.

II. The effect of vasopressin on the rate of equilibration of isotopic urea between renal cortex and medulla. The corrected specific activities of urea in the cortex, inner medulla and papilla in kidneys removed 5 minutes after initiation of $\mathrm{C}^{14}$-labeled urea infusion are shown in Table IV. Data from four paired experiments and one experiment $(\operatorname{Dog} J)$ in which only one kidney was removed are presented. It is apparent that in all kidneys the specific activity of the cortex is significantly higher than that of the papilla, indicating that the infused isotope was not equally distributed throughout the renal tissue. Since the infusion was continued throughout the 5 minute period, a rising plasma radioactivity was present. The gradient between cortex and papilla is attributable to a lag in the delivery of isotope to the inner medulla, whether the isotopic urea enters the medulla primarily by means of the medullary blood flow or by means of diffusion from the collecting duct. In order to assess the effect of vasopressin, the cortex to papilla gradient for $\mathrm{C}^{14}$-urea has been examined. In paired experiments, this gradient was always smaller during the infusion of vasopressin than during water diuresis, indicating that vasopressin augments the rate of delivery of isotope to the renal medulla. This finding is incompatible with the possibility that the effect of vasopressin

TABLE IV

$C^{14}$-urea specific activities ${ }^{*}$ in kidney slices following isotope infusion

\begin{tabular}{|c|c|c|c|c|c|c|c|c|}
\hline \multirow[b]{2}{*}{ Dog } & \multicolumn{4}{|c|}{ Water diuresis } & \multicolumn{4}{|c|}{ Vasopressin and mannitol } \\
\hline & Cortex & $\begin{array}{l}\text { Inner } \\
\text { medulla }\end{array}$ & Papilla & $\begin{array}{l}\text { Cortex/ } \\
\text { papilla }\end{array}$ & Cortex & $\begin{array}{c}\text { Inner } \\
\text { medulla }\end{array}$ & Papilla & $\begin{array}{l}\text { Cortex } \\
\text { papilla }\end{array}$ \\
\hline $\mathrm{H}$ & 85 & 65 & 64 & 1.33 & 234 & 224 & 202 & 1.16 \\
\hline I & 72 & 57 & 50 & 1.45 & 147 & 146 & 124 & 1.18 \\
\hline $\mathrm{J}$ & 126 & 104 & 97 & 1.29 & & & & \\
\hline $\mathrm{K}$ & 141 & 103 & 95 & 1.49 & 359 & 322 & 290 & 1.24 \\
\hline \multirow[t]{2}{*}{ I. } & 12.3 & 91 & 101 & 1.22 & 303 & 295 & 294 & 1.03 \\
\hline & \multicolumn{4}{|c|}{ Mean } & & & Mean & 1.15 \\
\hline
\end{tabular}

* Specific activities expressed in counts per minute per micromole of urea, corrected for quenching. 

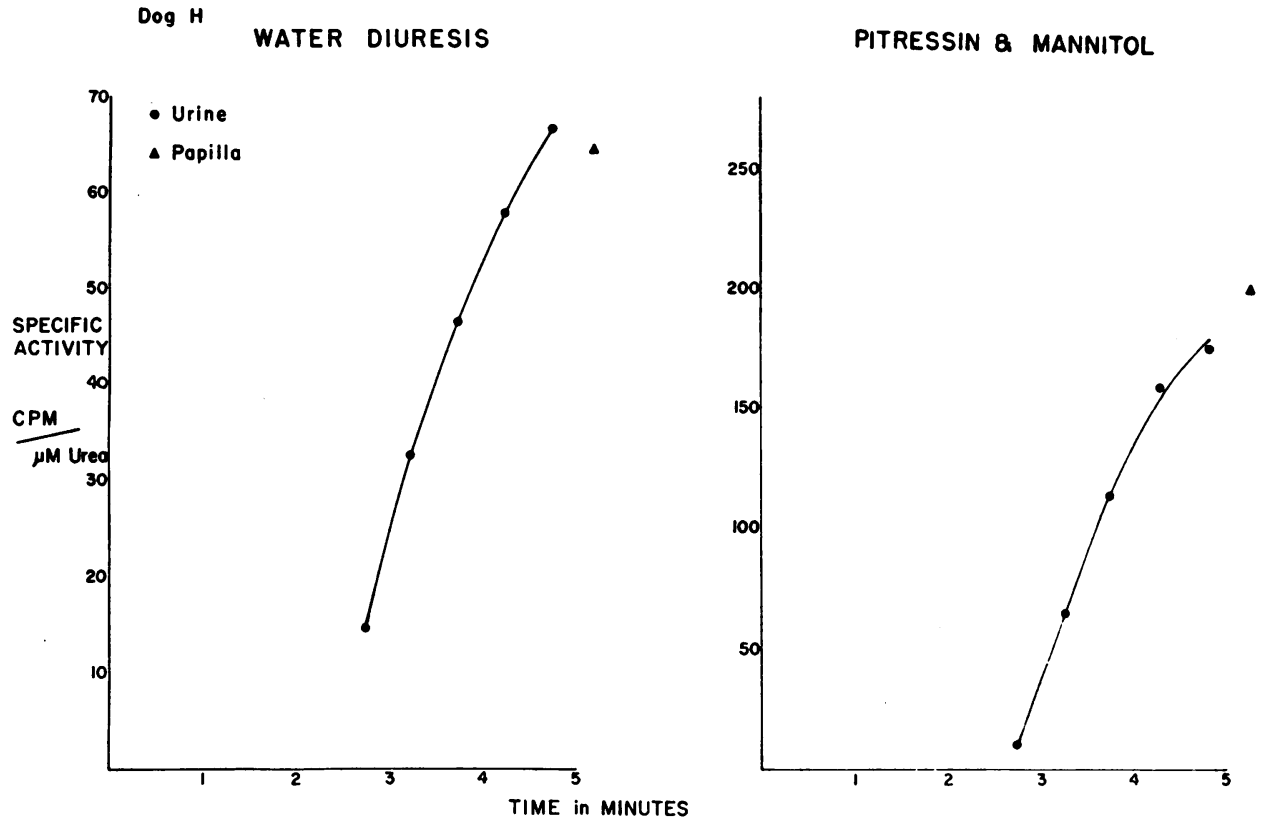

Fig. 1. The RELATIONSHip of URINARY AND RENAL PAPIllary SPECIFIC ACTIVItIES FollowING $C^{14}$-UREA INFUSION DURING WATER DIURESIS AND DURING VASOPRESSIN ADMINISTRATION. In each part of this paired experiment, the closed circles represent urinary specific activity; triangles represent the specific activity of the papilla from the respective kidney.

on the concentration gradients of urea between tissue and urine was secondary to more efficient trapping of urea in the medulla and a diminished rate of turnover of urea in that area.

Similar qualitative results were obtained in three other paired experiments, in which lack of correction for quenching precludes absolute quantitative comparison with the studies shown in Table IV.

III. The effect of vasopressin on the rate of equilibration of isotopic urea between urine and renal papilla. In the experiments discussed in the previous section, urinary specific activities were also determined during the time period following the initiation of the isotopic urea infusion. In Figure 1 the specific activity of the urine in five 30 -second collection periods, immediately preceding nephrectomy in a paired experiment, are plotted. In each part of the experiment, as in all other studies of this nature, the urinary specific activity was rising rapidly during this time period. The specific activity of the papilla from each kiclney is also plotted. During vasopressin and mannitol infusion the specific activity of the papilla was higher than that of the final urine period. This apparent discrepancy may be attributed to the time lag between the mid-point of the final urine collection period and the removal of the kidney, since it is eliminated by extrapolation of the urinary specific activity curve to the time at which nephrectomy was performed. Thus it is suggested that during vasopressin and mannitol administration there was essentially complete equilibration of isotopic urea between urine and renal papilla 5 minutes after beginning the infusion of isotope. In contrast, during water diuresis the specific activity of the papilla was slightly lower than that of the final urine, and this difference is magnified by extrapolation of the curve of urinary specific activity. This finding suggests that movement of labeled urea from collecting duct lumen into medullary interstitium was delayed in the absence of vasopressin.

A similar relationship has been found in four other dogs, in which corrected specific activities were obtained. In Table $\mathrm{V}$, the ratio of the papillary specific activity to that in the final urine has been computed in the same group of experiments shown in Table IV. In paired experiments, the tissue to urine specific activity ratio was consistently higher during the administration of vasopressin and mannitol. There is no overlap of 
TABLE $\mathrm{V}$

Relationship of $C^{\mathbf{1 4}}$-urea specific activity in renal papilla and urine

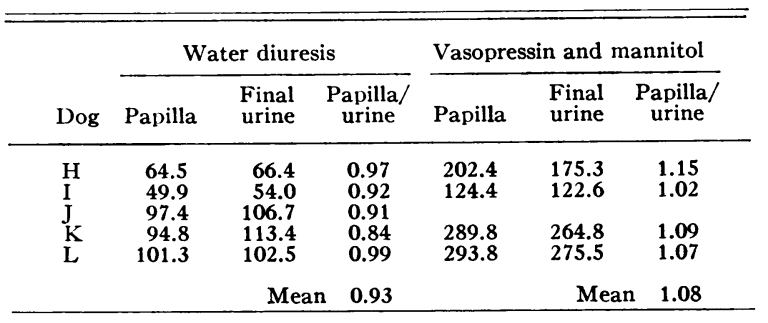

values when all experiments are examined; this ratio always exceeded unity during vasopressin action, and was less than 1 during water diuresis.

These data lend further support to the conclusions derived from the previously cited experiments, namely that vasopressin increases the permeability of the collecting duct epithelium to urea, and by this means promotes the movement of urea from tubular lumen to the medullary interstitial space.

\section{DISCUSSION}

The demonstration of an effect of vasopressin on the permeability of the collecting duct to urea suggests that this hormone increases the pore size in this epithelial membrane. By analogy with studies on other membranes $(8,9,11)$ it may be inferred that vasopressin also augments water permeability in this segment of the nephron, and that consequently the rate of achievement of osmotic equilibrium between collecting duct tubular fluid and extratubular medullary fluid is accelerated by an action of this hormone. The maintenance of a high osmotic gradient between the medullary interstitium and collecting duct fluid during water diuresis $(18,19)$ can be readily explained as a result of the restricted permeability to water in the absence of vasopressin. On the basis of these observations, it is suggested that the action of vasopressin on the collecting duct epithelium constitutes an important determinant in the processes of urinary concentration and dilution.

The present method of study does not permit a kinetic analysis of the movement of urea across the collecting duct epithelium. Whether vasopressin augments the diffusion of urea, or whether the increased rate of movement of urea is primarily a result of solvent drag imposed by the osmotic flow of water can not be determined. In either event, augmentation of urea accumulation in the medulla by the action of vasopressin serves to increase the degree to which the kidney can conserve water and concentrate the urine.

A hypothesis concerning the mechanism whereby urea contributes to the process of urinary concentration has been previously presented by Berliner, Levinsky, Davidson and Eden (18). The results of the present study are compatible with their formulation, and serve to emphasize that the unique role of urea is dependent upon special permeability characteristics of the collecting duct epithelium with respect to this molecule. This is illustrated by the following considerations. Complete impermeability to urea would preclude the movement of urea into the medullary interstitial space, and limit the solute concentration attainable in that space to the concentration of sodium chloride which can be achieved by active transport. This latter concentration would consequently determine the limit of maximal urinary osmolality. If the collecting duct offered no barrier to the diffusion of urea, the movement of water out of the tubule would be accompanied by urea at a concentration identical with that within the tubular fluid. Consequently, the urea concentration within the lumen would remain uniform along the length of the collecting duct. As a result, although urea would be added to the interstitial fluid solute, its contribution would be limited to that concentration of urea present in the fluid leaving the distal convolution. Clearly, the degree of permeability to urea in the collecting duct lies between these two extremes. There exists a sufficient barrier to diffusion to permit a rising concentration within the lumen as water is abstracted, yet movement of urea into the medullary interstitium is sufficient to add materially to the total solute concentration within the medulla.

Concentration of urea within the tubular fluid as it passes down the collecting duct is dependent upon osmotic abstraction of water by nonpermeating solute (sodium chloride) in the peritubular space. Osmotic movement of water will proceed until the interstitial sodium chloride is balanced by an osmotically equivalent concentration of nonpermeating solute within the tubular lumen. Urea, since it can penetrate the tubular epithelium, will exert little effective restriction to the continued 
movement of water out of the collecting duct. Consequently, the ratio of urea to nondiffusible solute in the fluid entering the collecting ducts from the distal convolution will determine in part the fraction of that fluid which can be abstracted from the tubule, and thus the extent to which urea can be concentrated within the tubular and interstitial fluids and ultimately contribute to urinary concentration. Thus, at comparable rates of solute excretion, urine osmolality is significantly higher during urea osmotic diuresis than when sodium chloride or mannitol is used as the loading solute $(20,21)$. In contrast, when urea constitutes a small fraction of the total solute entering the collecting duct, as in a subject fed a low protein diet, the contribution of urea to urinary concentration is minimized, and maximal concentrating ability is impaired $(13,22)$.

During dehydration, urea clearance-relative to filtration rate-diminishes (23), and the plasma urea concentration accordingly rises. It is suggested that these accompaniments of the dehydrated state are manifestations of the role of urea in renal water conservation. In the hydropenic animal elaborating a highly concentrated urine, the urea concentration within the renal medulla exceeds the total solute concentration in the plasma. In the dog, concentrations of 700 to 800 $\mu$ moles of urea per $g$ of water are frequently observed in the renal papilla (13). Barring an active transport process for urea, its concentration in the medulla can not exceed the net concentration of urea in the water entering the medullary interstitium from the collecting duct. Consequently, it may be concluded that in the hydropenic dog producing a highly concentrated urine, the fluid entering the papillary interstitium from the collecting duct contains sufficient urea so that it is hypertonic to the systemic body fluids. Since this process occurs physiologically only in the hydropenic state, it may be viewed as a homeostatic mechanism which acts to conserve body water at the expense of increasing body fluid osmolality. Since urea diffuses readily into the various body fluid compartments, the major need of the organism, maximal conservation of water, is subserved without incurring potentially detrimental fluid shifts between these compartments.

Recent studies indicate that animals residing in arid regions possess an unusually deep renal me- dulla and papilla (24), in contrast to certain species whose habitat is restricted to areas in which the water supply is abundant $(24,25)$. In addition to increasing the efficiency of the countercurrent mechanisms, this anatomical characteristic favors the achievement of the maximal attainable intratubular urea concentration and similarly increases the degree to which urea will attain diffusive equilibrium between tubular and peritubular fluids. These observations suggest that the role of urea in urinary concentration is vital to the maintenance of body fluid volume in the normal existence of certain animal species.

\section{SUM MARY}

The effect of vasopressin on the relative concentrations of urea within the renal medulla and within the urine has been determined in a set of paired steady state experiments in logs. In every experiment a higher tissue to urine concentration ratio for urea has been observed during vasopressin administration than during water diuresis. In additional studies in which $\mathrm{C}^{14}$-labeled urea was injected intravenously it was observed that the rate of appearance of isotopic urea in the renal medullary tissue is enhanced by vasopressin, suggesting that vasopressin increases the rate of turnover of urea within the renal medulla. Similarly, equilibration of labeled urea between urine and renal papilla was more rapid in the presence of vasopressin. These data indicate that the rate of movement of urea from the collecting duct lumen to the peritubular fluid is augmented by the action of vasopressin. Since this evidence favors the view that passage of urea out of the tubular fluid in the dog kilney is by means of passive diffusion along a concentration gradient, the present results are interpreted to indicate a direct effect of vasopressin on the permeability of the collecting duct epithelium.

\section{ACKNOWLEDGMENT}

The author gratefully acknowledges the advice and criticism offered by Dr. Robert W. Berliner throughout the course of this study. He also thanks Miss Agnes Scott Preston for her expert technical assistance.

\section{REFERENCES}

1. Wirz, H. The location of antidiuretic action in the mammalian kidney in The Neurohypophysis, $H$. Heller, Ed. New York, Academic Press, 1957, p. 157. 
2. Gottschalk, C. W., and Mylle, M. Micropuncture study of the mammalian urinary concentrating mechanism: Evidence for the countercurrent hypothesis. Amer. J. Physiol. 1959, 196, 927.

3. Ullrich, K. J., Drenckhahn, F. O., and Jarausch, K. H. Untersuchungen zum Problem der Harnkonzentrierung und -verdünnung. $\ddot{\mathrm{Cber}}$ das osmotische Verhalten von Nierenzellen und die begleitende Elektrolytanhäufung im Nierengewebe bei verschiedenen Diuresezuständen. Pflïg. Arch. ges. Physiol. 1955, 261, 62.

4. Levinsky, N. G., Davidson, D. G., and Berliner, R. W. Effects of reduced glomerular filtration on urine concentration in the presence of antidiuretic hormone. J. clin. Invest. 1959, 38, 730.

5. Gowenlock, A. H., Emery, E. W., Riddell, A. G., and Black, D. A. K. Intrarenal variations in sodium and potassium distribution. Clin. Sci. 1959, 18, 513.

6. Berliner, R. W., and Davidson, D. G. Production of hypertonic urine in the absence of pituitary antidiuretic hormone. J. clin. Invest. 1957, 36, 1416.

7. Jaenike, J. R., and Berliner, R. W. A study of distal renal tubular functions by a modified stop flow technique. J. clin. Invest. 1960, 39, 481.

8. Koefoed-Johnsen, V., and Ussing, H. H. The contributions of diffusion and flow to the passage of $\mathrm{D}_{2} \mathrm{O}$ through living membranes. Acta physiol. scand. 1953, 28, 60.

9. Andersen, B., and Ussing, H. H. Solvent drag on nonelectrolytes during osmotic flow through isolated toad skin and its response to antidiuretic hormone. Acta physiol. scand. 1957, 39, 228.

10. Klümper, J. D., Ullrich, K. J., and Hilger, H. H. Das Verhalten des Harnstoffs in den Sammelrohren der Säugetierniere. Pflüg. Arch. ges. Physiol. 1958, 267, 238.

11. Maffly, R. H., Hays, R. M., Lamdin, 'E., and Leaf, A. The effect of neurohypophyseal hormones on the permeability of the toad bladder to urea. J. clin. Invest. 1960, 39, 630.

12. Schmidt-Nielsen, B., and O'Dell, R. Effect of diet on distribution of urea and electrolytes in kidneys of sheep. Amer. J. Physiol. 1959, 197, 856.
13. Levinsky, N. G., and Berliner, R. W. The role of urea in the urine concentrating mechanism. J. clin. Invest. 1959, 38, 741.

14. Conway, E. J. Micro-Diffusion Analysis and Volumetric Error. London, Crosby, Lockwood and Son, 1957.

15. Walser, M., Davidson, D. G., and Orloff, J. The renal clearance of alkali-stable inulin. J. clin. Invest. 1955, 34, 1520.

16. Bowman, R. L., Trantham, H. V., and Caulfield, P. A. An instrument and method for rapid, dependable determination of freezing-point depression. J. Lab. clin. Med. 1954, 43, 310.

17. Snedecor, G. W. Statistical Methods Applied to Experiments in Agriculture and Biology. Ames, Iowa, State University Press, 1946.

18. Berliner, R. W., Levinsky, N. G., Davidson, D. G., and Eden, M. Dilution and concentration of the urine and the action of antidiuretic hormone. Amer. J. Med. 1958, 24, 730.

19. Bray, G. A. A study of the freezing point depression of rat kidney slices during water diuresis and antidiuresis. Amer. J. Physiol. In press.

20. Kellogg, R. H., and Koike, T. I. Difference between mannitol and urea diuresis in the rat (abstract). Amer. J. Physiol. 1955, 183, 633.

21. Jaenike, J. R. Urea enhancement of water reabsorption in the renal medulla. Amer. J. Physiol. In press.

22. Epstein, F. H., Kleeman, C. R., Pursel, S., and Hendrikx, A. The effect of feeding protein and urea on the renal concentrating process. J. clin. Invest. 1957, 36, 635.

23. Shannon, J. A. Glomerular filtration and urea excretion in relation to urine flow in the dog. Amer. J. Physiol. 1936, 117, 206.

24. O'Dell, R., and Schmidt-Nielsen, B. Concentrating ability and kidney structure. Fed. Proc. 1960, 19, 366.

25. Nungesser, W. C., Pfeiffer, E. W., Iverson, D. A., and Wallerius, J. F. Evaluation of renal countercurrent hypothesis in Aplodontia. Fed. Proc. 1960, 19,362 . 